\title{
Front Matter: Volume 10522
}

, "Front Matter: Volume 10522," Proc. SPIE 10522, Frontiers in Ultrafast Optics: Biomedical, Scientific, and Industrial Applications XVIII, 1052201 (23 May 2018); doi: 10.1117/12.2322856

SPIE. Event: SPIE LASE, 2018, San Francisco, California, United States 


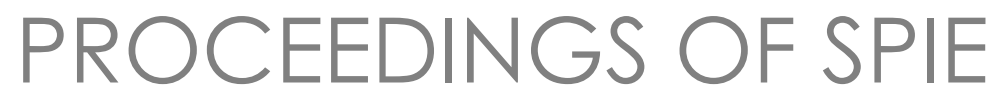

\title{
Frontiers in Ultrafast Optics: Biomedical, Scientific, and Industrial Applications XVIII
}

\author{
Peter R. Herman \\ Michel Meunier \\ Roberto Osellame \\ Editors
}

28-30 January 2018

San Francisco, California, United States

Sponsored by

SPIE

Cosponsored by

Amplitude Systèmes (France)

TRUMPF Inc. (United States)

Published by

SPIE 
The papers in this volume were part of the technical conference cited on the cover and title page. Papers were selected and subject to review by the editors and conference program committee. Some conference presentations may not be available for publication. Additional papers and presentation recordings may be available online in the SPIE Digital Library at SPIEDigitalLibrary.org.

The papers reflect the work and thoughts of the authors and are published herein as submitted. The publisher is not responsible for the validity of the information or for any outcomes resulting from reliance thereon.

Please use the following format to cite material from these proceedings:

Author(s), "Title of Paper," in Frontiers in Ultrafast Optics: Biomedical, Scientific, and Industrial Applications XVIII, edited by Peter R. Herman, Michel Meunier, Roberto Osellame, Proceedings of SPIE Vol. 10522 (SPIE, Bellingham, WA, 2018) Seven-digit Article CID Number.

ISSN: 0277-786X

ISSN: 1996-756X (electronic)

ISBN: 9781510615298

ISBN: 9781510615304 (electronic)

Published by

SPIE

P.O. Box 10, Bellingham, Washington 98227-0010 USA

Telephone +13606763290 (Pacific Time) · Fax +1 3606471445

SPIE.org

Copyright (C) 2018, Society of Photo-Optical Instrumentation Engineers.

Copying of material in this book for internal or personal use, or for the internal or personal use of specific clients, beyond the fair use provisions granted by the U.S. Copyright Law is authorized by SPIE subject to payment of copying fees. The Transactional Reporting Service base fee for this volume is $\$ 18.00$ per article (or portion thereof), which should be paid directly to the Copyright Clearance Center (CCC), 222 Rosewood Drive, Danvers, MA 01923. Payment may also be made electronically through CCC Online at copyright.com. Other copying for republication, resale, advertising or promotion, or any form of systematic or multiple reproduction of any material in this book is prohibited except with permission in writing from the publisher. The CCC fee code is 0277 $786 \mathrm{X} / 18 / \$ 18.00$.

Printed in the United States of America.

Publication of record for individual papers is online in the SPIE Digital Library.

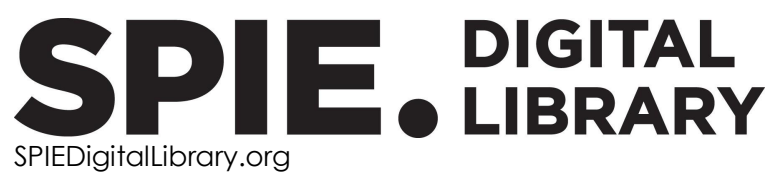

Paper Numbering: Proceedings of SPIE follow an e-First publication model. A unique citation identifier (CID) number is assigned to each article at the time of publication. Utilization of CIDs allows articles to be fully citable as soon as they are published online, and connects the same identifier to all online and print versions of the publication. SPIE uses a seven-digit CID article numbering system structured as follows:

- The first five digits correspond to the SPIE volume number.

- The last two digits indicate publication order within the volume using a Base 36 numbering system employing both numerals and letters. These two-number sets start with $00,01,02,03,04$, 05, 06, 07, 08, 09, 0A, OB ... 0Z, followed by 10-1Z, 20-2Z, etc. The CID Number appears on each page of the manuscript. 


\title{
Contents
}

\author{
$\checkmark \quad$ Authors \\ vii Conference Committee \\ ix Introduction
}

BIOMEDICAL APPLICATIONS OF ULTRAFAST LASERS

$1052203 \quad$ Femtosecond laser-triggered molecular release from biodegradable polymer microcapsules incorporated in gelatin hydrogel [10522-2]

1052205 Scattering properties of ultrafast laser-induced refractive index shaping lenticular structures in hydrogels [10522-4]

SURFACE STRUCTURING WITH ULTRAFAST LASERS

10522 OF Surface functionalization of metal surfaces by large-area USP laser texturing [10522-13]

$105220 \mathrm{O} \quad$ Plasmonic colours on bulk metals: laser colouring of large areas exhibiting high topography (Invited Paper) [10522-14]

\section{NOVEL TECHNIQUES FOR MATERIAL CHARACTERIZATION}

$10522 \mathrm{OH} \quad$ Beam shaping and in-situ diagnostics for development of transparent materials processing (Invited Paper) [10522-15]

$10522 \mathrm{Ol} \quad$ Supercontinuum generation in large-mode-area photonic crystal fibers for coherent Raman microspectroscopy [10522-16]

\section{ADVANCES IN ULTRAFAST LASER ABLATION}

10522 OS Suppression of ablation by double-pulse femtosecond laser irradiation (Invited Paper) [10522-25]

10522 OU Which period ripples will form on the ablated surface: subwavelength or deep-subwavelength? (Invited Paper) [10522-27] 
1052210 Generation of TW-scale mid-IR femtosecond pulses using a dual-chirped optical parametric amplification (Invited Paper) [10522-33]

$1052211 \quad$ Material processing with fiber based ultrafast pulse delivery [10522-34]

\section{D GLASS MODIFICATION}

$1052216 \quad$ Glass cutting optimization with pump-probe microscopy and Bessel beam profiles [10522-39]

1052217 Distortion-compensated multifocusing of ultrashort pulse beams using a cascade optical system [10522-40]

\section{POSTER SESSION}

$105221 \mathrm{E} \quad$ Single-shot temporal characterization of kilojoule-level, picosecond pulses on OMEGA EP [10522-46]

10522 IF High-speed 'multi-grid' pulse-retrieval algorithm for frequency resolved optical gating [10522-47]

$105221 \mathrm{H} \quad$ One-step synthesis of three-dimensional microtubes with single exposure of structured femtosecond optical vortices [10522-49]

$1052211 \quad$ Enhanced ablation with a femtosecond-nanosecond dual-pulse [10522-51]

$105221 \mathrm{M} \quad$ Switching waves dynamics in optical bistable cavity-free system at femtosecond laser pulse propagation in semiconductor under light diffraction [10522-55]

$105221 \mathrm{~N} \quad$ Short pulse characterization requires recognizing inseparability of auto-correlation and spectral measurements [10522-56]

10522 is The laser-only single-event effects test method for space electronics based on ultrashortpulsed-laser 'local irradiation' [10522-61]

$105221 \mathrm{U} \quad$ Qualitative analysis of single shot ablation craters with ultra-short pulses [10522-63]

$105221 \mathrm{~V} \quad$ Rapid prototyping of 2D glass microfluidic devices based on femtosecond laser assisted selective etching process [10522-64] 


\title{
Authors
}

Numbers in the index correspond to the last two digits of the seven-digit citation identifier (CID) article numbering system used in Proceedings of SPIE. The first five digits reflect the volume number. Base 36 numbering is employed for the last two digits and indicates the order of articles within the volume. Numbers start with 00, 01, 02, 03, 04, 05, 06, 07, 08, 09, OA, OB...0Z, followed by 10-12, 20-2Z, etc.

\author{
Amako, J., 17 \\ Baumbach, S., 11 \\ Berini, Pierre, OG \\ Bittle, W., $1 \mathrm{E}$ \\ Brooks, Daniel R., 05 \\ Budnicki, A., 11 \\ Butler, Sam C., 05 \\ Calà Lesina, Antonino, $0 G$ \\ Choi, Jiyeon, IV \\ Chu, Jiaru, $1 \mathrm{H}$ \\ Chumakov, Alexander I., is \\ de Assis, Pierre-Louis, OU \\ Dorrer, C., $1 \mathrm{E}$ \\ Egorenkov, Vladimir A., 1M \\ Egorov, Andrey N., is \\ Ellis, Jonathan D., 05 \\ Faucon, Marc, OF \\ Flamm, D., $\mathrm{OH}, 16$ \\ Fu, Yuxi, 10 \\ Führa, B., 11 \\ Furukawa, Yuki, OS \\ Gemini, Laura, OF \\ Germer, Thomas A., 05 \\ Grossmann, D., OH, 16 \\ Guay, Jean-Michel, OG \\ Hashida, Masaki, OS \\ Hellstern, Julian, 16 \\ Hill, E. M., $1 \mathrm{E}$ \\ $\mathrm{Hu}, \mathrm{Kai}, 1 \mathrm{H}$ \\ $\mathrm{Hu}$, Yanlei, $1 \mathrm{H}$ \\ $\mathrm{Hu}$, Zhijiang, $\mathrm{IH}$ \\ Huxlin, Krystel R., 05 \\ Inoue, Shunsuke, OS \\ Jafari, Rana, IF \\ Jenne, M., OH, 16 \\ Joung, Yeun-Ho, $1 \mathrm{~V}$ \\ Juodkazis, Saulius, OU \\ Kaiser, E., 11 \\ Kalb, A., 1E \\ Kanal, F., 11 \\ Katkus, Tomas, OU \\ Kerrigan, Haley, $11,1 \mathrm{U}$ \\ Killi, A., 11 \\ Kim, Jeongtae, IV \\ Kim, Sung-II, IV \\ Kleiner, J., $\mathrm{OH}$ \\ Kling, Rainer, OF \\ Koo, Chiwan, IV \\ Krupin, Oleksiy, OG
}

\author{
Kumkar, M., OH, 16 \\ Kusaba, Mitsuhiro, OS \\ $\mathrm{Li}$, Jiawen, $1 \mathrm{H}$ \\ Linklater, Denver P., OU \\ Loginova, Maria M., IM \\ Lundgaard, Stefan, OU \\ Maier, D., 11 \\ Malinauskas, Mangirdas, oU \\ Masuno, Shinichiro, OS \\ Mavritskii, Oleg B., 1S \\ Midorikawa, Katsumi, 10 \\ Moosmann, J., 11 \\ Moshkalev, Stanislav, ou \\ Moulton, Simon E., OU \\ Nakano, H., 17 \\ $\mathrm{Ng}$, Soon Hock, OU \\ Nishimura, Kotaro, 10 \\ Nishino, Shogo, OS \\ Nolte, S., $\mathrm{OH}, 16$ \\ O'Connor, Sean P., Ol \\ Ouaj, T., 16 \\ Pechenkin, Alexander A., is \\ Prasad, Narasimha S., iN \\ Pricking, S., 11 \\ Ramunno, Lora, OG \\ Richardson, Martin, 11, $1 \mathrm{U}$ \\ Rostami Fairchild, Shermineh, 11, $1 \mathrm{U}$ \\ Roychoudhuri, Chandrasekhar, iN \\ Russ, S., 11 \\ Sakabe, Shuji, OS \\ Sakagami, Hitoshi, OS \\ Savchenkov, Dmitriy V., is \\ Scully, Marlan O., Ol \\ Shen, Yujie, 01 \\ Sokolov, Alexei $\mathrm{V} ., \mathrm{Ol}$ \\ Stockburger, R., 11 \\ Suda, Akira, 10 \\ Sudesh, Vikas, $1 \mathrm{U}$ \\ Sutter, D. H., 11 \\ Takahashi, Eiji J., 10 \\ Terakawa, M., 03 \\ Thum, S., 11 \\ Trebino, Rick, 1F \\ Trofimov, Vyacheslav A., $1 \mathrm{M}$ \\ Tsukamoto, Masahiro, OS \\ Umemoto, T., 03 \\ Varapnickas, Simonas, OU \\ Voronin, Alexander A., 01 \\ Walia, Jaspreet, OG
}


Waxer, L. J., 1E

Weber, Daniel Perry, $1 \mathrm{U}$

Weck, Arnaud, OG

Wozniak, Kaitlin T., 05

Wu, Dong, $1 \mathrm{H}$

Xin, Chen, $1 \mathrm{H}$

Yakovlev, Vladislav V., Ol

Yang, Liang, $1 \mathrm{H}$

Zheltikov, Aleksei M., 이

Zimmermann, F., $\mathrm{OH}$

Zoller, S., 11

Proc. of SPIE Vol. 10522 1052201-6

Downloaded From: https://www.spiedigitallibrary.org/conference-proceedings-of-spie on 25 Apr 2023 Terms of Use: https://www.spiedigitallibrary.org/terms-of-use 


\section{Conference Committee}

Symposium Chairs

Koji Sugioka, RIKEN (Japan)

Reinhart Poprawe, Fraunhofer-Institut für Lasertechnik (Germany)

Symposium Co-chairs

Xianfan Xu, Purdue University (United States)

Beat Nevenschwander, Berner Fachhochschule Technik und Informatik (Switzerland)

Program Track Chairs

Henry Helvajian, The Aerospace Corporation (United States)

Guido Hennig, Daetwyler Graphics AG (Switzerland)

\section{Conference Chairs}

Peter R. Herman, University of Toronto (Canada)

Michel Meunier, Ecole Polytechnique de Montréal (Canada)

Roberto Osellame, CNR-Istituto di Fotonica e Nanotecnologie (Italy)

Conference Program Committee

Craig B. Arnold, Princeton University (United States)

Yves Bellouard, Ecole Polytechnique Fédérale de Lausanne

(Switzerland)

Adela Ben-Yakar, The University of Texas at Austin (United States)

Alexander Heisterkamp, Leibniz Universität Hannover (Germany)

Denise M. Krol, University of California, Davis (United States)

Eric Mazur, Harvard University (United States)

Eric P. Mottay, Amplitude Systèmes (France)

Beat Neuenschwander, Berner Fachhochschule Technik und Informatik (Switzerland)

Stefan Nolte, Friedrich-Schiller-Universität Jena (Germany)

Christopher B. Schaffer, Cornell University (United States)

Koji Sugioka, RIKEN (Japan)

Mitsuhiro Terakawa, Keio University (Japan)

Alfred Vogel, Universität zu Lübeck (Germany)

Sascha Weiler, TRUMPF Inc. (United States)

Dvir Yelin, Technion-Israel Institute of Technology (Israel) 
Session Chairs

1 Biomedical Applications of Ultrafast Lasers

Michel Meunier, Ecole Polytechnique de Montréal (Canada)

2 Ultrafast Laser Interaction with Cells and Tissues

Aleksandr Ovsianikov, Technische Universität Wien (Austria)

3 Surface Structuring with Ultrafast Lasers

Malte Kumkar, TRUMPF Laser- und Systemtechnik GmbH (Germany)

4 Novel Techniques for Material Characterization

Jan Siegel, Instituto de Óptica "Daza de Valdés" (Spain)

5 Ultrafast Laser Writing of Waveguide and Fiber Devices

Roberto Osellame, CNR-Istituto di Fotonica e Nanotecnologie (Italy)

6 Advances in Ultrafast Laser Ablation

Peter R. Herman, University of Toronto (Canada)

7 Laser-assisted Chemical Structuring of Glasses

Saulius Juodkazis, Swinburne University of Technology (Australia)

8 Advanced Ultrafast Lasers for Material Processing

Eric P. Mottay, Amplitude Systèmes (France)

9 3D Glass Modification

Stefan Nolte, Friedrich-Schiller-Universität Jena (Germany)

10 3D Crystal Structuring

Yves Bellouard, Ecole Polytechnique Fédérale de Lausanne (Switzerland) 


\section{Introduction}

Ultrafast lasers are now ubiquitous in scientific studies through biomedical and industrial applications. The papers in this year's program and proceedings reflect the rapid progress that has been made in development of high-powered femtosecond laser systems, providing users with a wider berth of wavelength and exposure conditions on which to further develop the field. Papers on laser-matter interaction physics point to new avenues for nano-structuring of surfaces to controlling the internal modification of transparent materials and tissue. Improved means for laser beam controls and process monitoring systems are further addressing the challenges to scale up processing speeds and support the expansion of commercial applications across a wide spectrum of industry to medical directions. The papers in these proceedings provide the state-of-art view of ultrafast laser technology, their novel interactions with materials, and the application directions that continue to expand and grow, representing an exciting future direction for the field.

\section{Peter R. Herman \\ Michel Meunier Roberto Osellame}


Proc. of SPIE Vol. 10522 1052201-10 Downloaded From: https://www.spiedigitallibrary.org/conference-proceedings-of-spie on 25 Apr 2023
Terms of Use: https://www.spiedigitallibrary.org/terms-of-use 